\title{
Memorial Resolution for Peter Leo Kraus
}

WHEREAS, the American Library Association (ALA) and the academic library community lost a valued member on April 5th, 2020, with the death of Peter Leo Kraus;

WHEREAS, he was member of ALA GODORT for nearly 25 years;

WHEREAS, he was an active member of the Utah Library Association GODORT and participated in advocacy activities;

WHEREAS, he served on government relations committees during his time as an academic librarian at The Research Libraries of The New York Public Library;

WHEREAS, he worked at the J. Willard Marriott Library at the University of Utah for over twenty years;

WHEREAS, during his library career and changing library responsibilities, he promoted the use and importance of government information and data to the students, staff, faculty of the University of Utah and citizens of Utah;

WHEREAS, he used his knowledge of government to teach Utah Academic Library Consortium directors, about the legislative process, resulting in dramatic budget increases;

WHEREAS, he served on faculty senate committee for community and government relations at the University of Utah;

WHEREAS, he regularly published on a wide variety of topics including running for elected office;

WHEREAS, he put his knowledge into the practice civic engagement, working for political candidates, serving on the Utah Humanities Council for two years, and in 2014, and 2018 and ran for a House Seat 40 in the Utah Legislature;

WHEREAS, he continued his education internationally through study at St. Stephen's House at the University of Oxford, UK, Pusey House in Oxford;

WHEREAS, he was widely recognized for his expertise and valued research support to faculty and graduate students in the Departments of Political Science $\&$ Public Administration, History and was a pioneer of the Block $U$ program as implemented at the David Eccles School of Business.
WHEREAS, he was a founder of the "DOCMAPS CIT" (Government Documents and Maps College and Interdisciplinary Team) at Marriott Library.

WHEREAS, he tirelessly advocated for the Marriott Library specifically as well as all libraries and their important role in higher education;

RESOLVED, that the American Library Association (ALA), on the behalf of its members:

1. recognizes the contributions of Peter Leo Kraus to the field of librarianship, and to the specialty of government information;

2. morns the loss of a mentor whose exchange of professional knowledge crossed national and international boundaries;

3. extends its sincerest sympathy to his family, friends, and colleagues at the University of Utah, and the J. Willard Marriott Library.

Mover: Lynda Kellam, 607.255.1359, lmk277@cornell.edu

Seconder: Andie Craley, acraley@harf ord.edu

Final version: 6/9/2020 